\title{
Foliar application of biofertilizer in semi-hydroponic lettuce fertigated with saline nutrient solution
} \author{
Maria Williane de Lima Souza ${ }^{2}$, Tatianne Raianne Costa Alves²® \\ 'São Paulo State University, Botucatu, Brazil \\ ${ }^{2}$ Federal Rural University of the Semi-Arid, Mossoró, Brazil \\ *Corresponding author, e-mail: caioleal3@hotmail.com
}

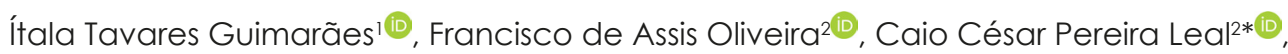

\begin{abstract}
Water scarcity in the world is a problem diagnosed especially in countries with large semi-arid regions such as Brazil. Research has been conducted with a view to making use of saline waters as an input for cultivation, particularly in hydroponics, with especial focus on lettuce, the most prominent leafy vegetable in Brazil. The objective of this study was to evaluate the development of lettuce in a semi-hydroponic system fertigated with saline water and under foliar fertilization with biofertilizer. The present study was carried out in a greenhouse located in the experimental area of the Department of Environmental and Technological Sciences (DCAT) of the Federal Rural University of the Semi-Arid Region, in the municipality of Mossoró, RN, Brazil. The experimental design was a randomized complete block design, with treatments arranged in a $2 \times 4$ factorial scheme, with 4 replicates, two salinity levels of the water used to prepare the nutrient solution $\left(0.5\right.$ and $\left.3.5 \mathrm{dS} \mathrm{m}^{-1}\right)$ and four biofertilizer concentrations $(0,20,40$ and $60 \%)$ applied by foliar spraying. The evaluated characteristics were: shoot diameter, stem diameter, number of leaves, fresh mass, dry mass, leaf succulence, leaf area and specific leaf area. The use of saline water to prepare the nutrient solution reduces fresh mass and dry mass production in the lettuce crop. The biofertilizer can be applied through the leaves at concentration of up to $20 \%$, promoting greater plant growth.
\end{abstract}

Keywords: Hydroponics, Lactuca sativa, salinity

\section{Introduction}

The Brazilian semi-arid region has edaphoclimatic characteristics that favor the scarcity of surface water and groundwater, with regard to the available quantity and quality, which may limit or prevent their use for various purposes (Araújo, 2011). Given the low offer of drinking water, it is important to conduct research to generate technologies that enable saline water to be used in food production (Paulus et al., 2010).

Agriculture is a sector that faces major negative impact when carried out in areas with salinity problems, be it in soil or in irrigation water, because when salts are present in the root zone of crops, they usually cause deleterious effect on plant growth (Holanda et al., 2010).

Water consumption by leafy vegetables is influenced by the increase of water salinity, which causes reductions in the osmotic potential of the plant, hampering the absorption of nutrients and reducing evapotranspiration, development and production of the crop (Silva et al., 2005; Soares et al., 2010). As a consequence, salinity reduces the photosynthetic capacity of plants, due to stomatal and non-stomatal limitations, which causes reduction in growth and yield (Silva et al., 2013; Gomes et al., 2011).

Thus, there emerges a need for the adoption of technologies that enable the use of saline water without significant reduction in production, such as semihydroponic cultivation, because in this cultivation system the tolerance of plants to salinity is higher compared to that observed in the conventional system, due to the absence of matric potential, which reduces as much as possible the harmful effects of salinity at the different growth stages (Santos Júnior et al., 2015).

In this context, research has been conducted with a view to enabling the use of saline water as an input for hydroponic cultivation, and the focus is mainly 
on lettuce (Paulus et al., 2010; Santos et al., 2010; Soares et al., 2010).

In the literature there are several studies on the effect of the use of saline water and biofertilizer on several species of agronomic interest, such as cowpea (Silva et al., 2011), papaya (Mesquita et al., 2012) and corn (Sousa et al., 2012), among others. In these studies, the authors observed that the use of biofertilizer did not inhibit, but reduced the effect of salinity on plants; in addition, the authors verified that the beneficial effects of the application of bovine biofertilizer on growth, gas exchange and nutrient extraction are less significant at the higher levels of irrigation water salinity.

There are still fewstudies with vegetables about the effect of the use of biofertilizer on plants subjected to salt stress, so the objective was to evaluate the development of lettuce in a hydroponic system fertigated with saline water and under foliar fertilization with biofertilizer.

\section{Material and Methods}

The experiment was conducted in a greenhouse located in the experimental area of the Department of Agronomic and Forestry Sciences of the Federal Rural University of the Semi-Arid Region (UFERSA), in the

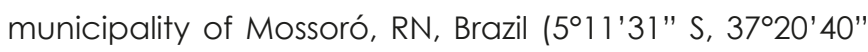
$W$, average altitude of $18 \mathrm{~m}$ ).

The experimental design used was randomized blocks, with treatments arranged in a $2 \times 4$ factorial scheme, with 4 replicates, two levels of salinity in the water used to prepare the nutrient solution 10.5 and $3.5 \mathrm{dS}$ $\left.\mathrm{m}^{-1}\right)$ and four concentrations of biofertilizer $(0,20,40$ and $60 \%$ ) applied via foliar spraying using a backpack sprayer with capacity for 5 liters. Each replicate was represented by four pots with capacity for $3 \mathrm{~L}$ of substrate, containing coconut fiber, with one plant in each pot.

The biofertilizer used was based on earthworm humus in the proportion of $10 \%$, prepared in a PVC container with capacity for $500 \mathrm{~L}$, which received $50 \mathrm{~kg}$ of earthworm humus and $450 \mathrm{~L}$ of water. The solution was stirred for 1 minute, at least twice a day, being ready between 5 and 8 days for full release of nutrients to the water.

The seedlings used were leaf lettuce, cv. Elba, produced in polypropylene trays with 200 cells, using earthworm humus as substrate. One seedling was placed in each pot, which were later arranged on a wooden bench at $0.50 \mathrm{~m}$ height from the ground, at spacing of $0.25 \times 0.25 \mathrm{~m}$ between plants.

The irrigation system was composed of two PVC tanks (300 L), one for each nutrient solution, lateral lines with $16 \mathrm{~mm}$ in diameter and microtube emitters with 0.8 $\mathrm{mm}$ of internal diameter and $20 \mathrm{~cm}$ in length, with average flow rate of $2.5 \mathrm{~L} \mathrm{~h}^{-1}$. The nutrient solution was injected using a self-venting Metalcorte/Eberle circulating electric pump, EBD250076 model (actuated by single-phase motor, $210 \mathrm{~V}$ voltage, $60 \mathrm{~Hz}$ frequency). Irrigation control was performed using a timer (Digital Timer), programmed for six irrigation events (07h00min; 09h00min; 11 h00min; 13h00min; 15h00min and 17h00min), with duration of one minute from transplantation (DAT) until 15 DAT and of two minutes from 15 DAT until harvest, which was carried out at 30 DAT.

The standard solution adopted followed the recommendation of Furlani et al. (1999), containing the following amounts of fertilizers, in $\mathrm{mg} \mathrm{L}^{-1}$ : 750 of calcium nitrate; 500 of potassium nitrate; 150 of monoammonium phosphate; and 400 of magnesium sulfate. The micronutrients were supplied through the addition of a chelated compound (Rexolin ${ }^{\circledR}$ BRA Yara), at a dose of 30 grams of the compound for every 1,000 L of nutrient solution. In order to adjust of the $\mathrm{pH}$ of the solution to be between 6.0 and $6.5,0.1 \mathrm{~mol} \mathrm{~L}^{-1}$ solutions of $\mathrm{KOH}$ or $\mathrm{HCl}$ were applied according to the need for increase or decrease in $\mathrm{pH}$. The electrical conductivity of the water used to prepare each solution was measured with a benchtop conductivity meter, determining values of 0.5

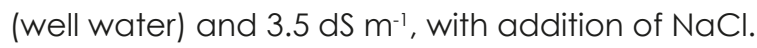

Harvest was carried out at 30 days after transplantation, and the following variables were analyzed: shoot diameter (ShD), obtained by measuring the plant shoots using a graduated ruler, considering the average diameter of two perpendicular means, expressed in cm; stem diameter (StD), obtained using a digital caliper in the stem region close to the substrate and expressed in $\mathrm{mm}$; number of leaves (NL), obtained by counting only leaves that showed commercial standard; fresh mass (FM), obtained by weighing the plants on a precision analytical scale $(0.01 \mathrm{~g})$; dry mass (DM), determined after drying the plants in a forced air circulation oven at temperature of $65^{\circ} \mathrm{C}$, until reaching constant weight.

In addition to these variables, the following parameters were determined: leaf area, by the leaf disc method according to the methodology of Souza et al. (2012); specific leaf area - SLA (ratio between leaf area and leaf dry mass) and leaf succulence - LS (ratio between leaf water content and leaf area). Leaf area was determined by the leaf disc method using a volumetric ring with internal diameter of $2.5 \mathrm{~cm}\left(4.9 \mathrm{~cm}^{2}\right)$, collecting 20 leaf discs per plot. The leaf discs were placed in paper bags and dried in a forced air circulation oven 
at temperature of $65^{\circ} \mathrm{C}$ until reaching constant weight.

The obtained data were subjected to analysis of variance, with further analysis of the factors for variables that showed significant response to the interaction between factors. The means were compared by Tukey test at $5 \%$ probability level to evaluate the effect of salinity, and regression analysis was used to evaluate the effect of biofertilizer doses. Statistical analyses were performed using SISVAR software (Ferreira, 2011).

\section{Results and Discussion}

Data analysis revealed that there was a significant effect of the interaction between salinity and biofertilizer for the variables stem diameter (StD), leaf area (LA), total marketable fresh mass (MFM), total dry mass (TDM), specific leaf area (SLA), leaf succulence (LS) at $5 \%$ probability level, with no significant interaction for the other variables. The variables shoot diameter (ShD) and total number leaves (TNL) were significantly affected by the biofertilizer factor at $1 \%$ probability level (Table 1).

Table 1. Summary of analysis of variance (mean squares) for shoot diameter (ShD), stem diameter (StD), number of marketable leaves (NML), leaf area (LA), marketable fresh mass (MFM), total dry mass (TDM), specific leaf area (SLA) and leaf succulence (LS) of lettuce grown in semi-hydroponics in saline solution with foliar application of biofertilizer.

\begin{tabular}{cccccc}
\hline Variables & Salinity & Biofertilizer & Sal x Bio & Residual & CV (\%) \\
\hline ShD & $0.16^{\mathrm{ns}}$ & $270.18^{* *}$ & $19.23^{\mathrm{ns}}$ & 12.79 & 12.38 \\
StD & $3.19^{\mathrm{ns}}$ & $30.07^{* *}$ & $5.19^{*}$ & 1.63 & 10.29 \\
NML & $0.63^{\mathrm{ns}}$ & $166.34^{* *}$ & $0.07^{\mathrm{ns}}$ & 4.42 & 11.97 \\
LA & $1623920.72^{*}$ & $21882250.14^{* *}$ & 1931560.51 & 261733 & 18.13 \\
MFM & $1715.79^{*}$ & $29376.74^{* *}$ & $1315.18^{*}$ & 346.04 & 17.12 \\
TDM & $15.43^{*}$ & $85.30^{* *}$ & $13.87^{*}$ & 2.34 & 16.88 \\
SLA & $22249.06^{*}$ & $24126.95^{*}$ & $18461.01^{*}$ & 1520.34 & 22.56 \\
LS & $0.0012^{* *}$ & $0.00049^{*}$ & $0.0028^{*}$ & 0.00013 & 21.88 \\
\hline
\end{tabular}

Lettuce shoot diameter was similarly affected by both levels of salinity, showing a quadratic response, with the highest value $(35.01 \mathrm{~cm})$ obtained at the biofertilizer concentration of $22.77 \%$. By comparing this value with that obtained in the absence of biofertilizer $(30.242 \mathrm{~cm})$, it was possible to note an increase of $15.77 \%$ (Figure 1). Similar results were obtained by Pereira et al. (2010), when working with biofertilizer produced with bovine manure, in which plants subjected to the application of this input at concentration of $20 \%$ had a larger shoot diameter.

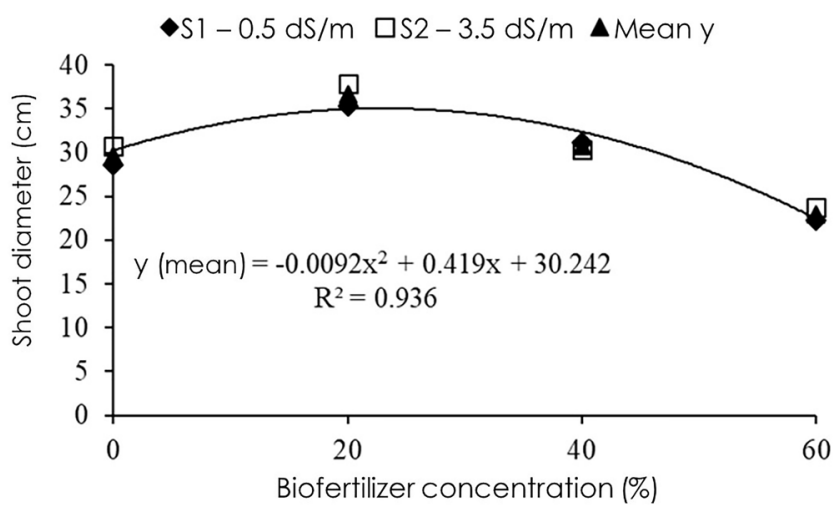

Figure 1. Shoot diameter of lettuce in semi-hydroponics in saline solution and under foliar application of biofertilizer.

In addition, it was observed that there was no significant effect of salinity on stem diameter. These results differ from those obtained by Viana et al. (2001), who worked with lettuce grown in soil and verified a reduction in shoot diameter with the use of saline water.
This divergence can be attributed to the cultivar used and to the cultivation system, because the cultivation in substrate increases the tolerance of the plant to salinity (Soares et al., 2007).

The use of the solution with biofertilizer interfered with stem diameter for both levels of salinity. There was a quadratic response in plants irrigated with non-saline solution, with the highest value $(15.60 \mathrm{~mm})$ obtained at concentration of $25.23 \%$. Plants subjected to salt stress showed a linear and positive response to the increase in biofertilizer concentration, and the highest value was obtained at the concentration of $60 \%$ (14.04 mm). It is also observed that salinity reduced stem diameter at biofertilizer concentrations 0 and $20 \%$, but increased it at the concentration of $60 \%$ (Figure 2).

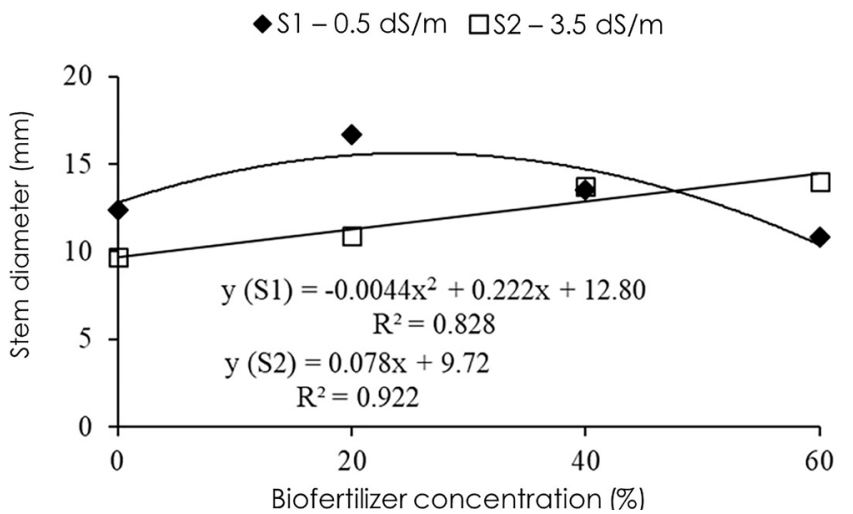

Figure 2. Stem diameter of lettuce grown in semi-hydroponics in saline solution and under foliar application of biofertilizer. 
Thus, it can be observed that the use of biofertilizer at the highest concentration inhibited the effect of salinity on stem diameter. Reduction of this variable in lettuce irrigated with saline water was observed by Santos et al. (2010).

There was no effect of salinity on the number of marketable leaves for any of the biofertilizer concentrations. The use of biofertilizer similarly affected the number of leaves at both levels of salinity, and the data were best described by the quadratic model, with highest value (22 leaves) at the concentration of $21.06 \%$. It is also verified that the use of biofertilizer at the highest concentration (60\%) led to reduction in the number of leaves, resulting in only 13 leaves (Figure 3). Divergent results are found in the literature on salinity and number of leaves, since some authors have observed reduction in leaf production (Santos et al., 2010; Oliveira et al., 2011), while others found no significant response (Guimarães et al., 2016).

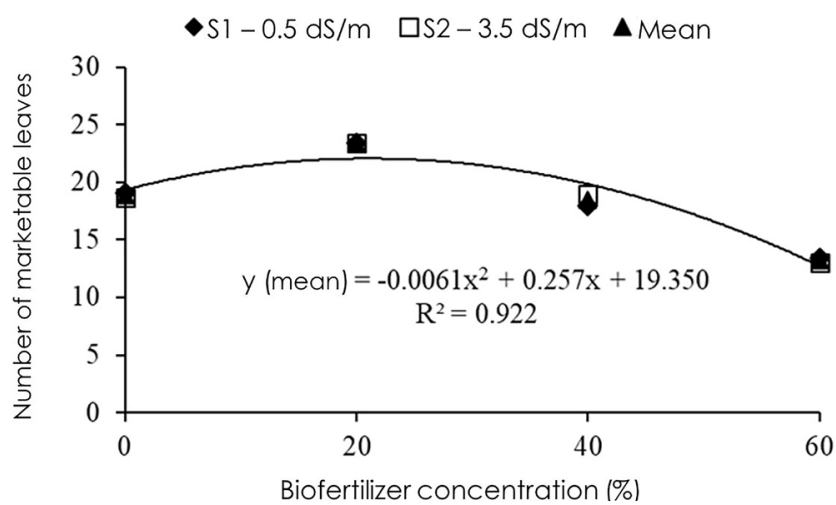

Figure 3. Number of marketable leaves of lettuce grown in semihydroponics in saline solution and under foliar application of biofertilizer.

As observed for the number of leaves, there was also no significant effect of salinity on leaf area. For both salinity levels, leaf area was quadratically affected by the increase in biofertilizer concentrations, with the highest value obtained at the concentration of $22.83 \%(4,606.73$ $\mathrm{cm}^{2}$ ). By comparing this value to that obtained in the absence of biofertilizer $\left(3,269.0 \mathrm{~cm}^{2}\right)$, it is possible to see an increase of $40.92 \%$. However, it was also verified that the biofertilizer concentration of $22.83 \%$ caused reduction in leaf area, so that the highest concentration (60\%) led to the smallest leaf area $\left(1,059.8 \mathrm{~cm}^{2}\right)$, which was $67.58 \%$ lower than that obtained in the absence of biofertilizer (Figure 4).

These results differ from those found in other studies with lettuce grown in NFT hydroponic system (Paulus et al., 2012; Soares et al., 2016) or in coconut fiber (Santos et al., 2012; Dias et al., 2011). The divergence between the results obtained in the present study for

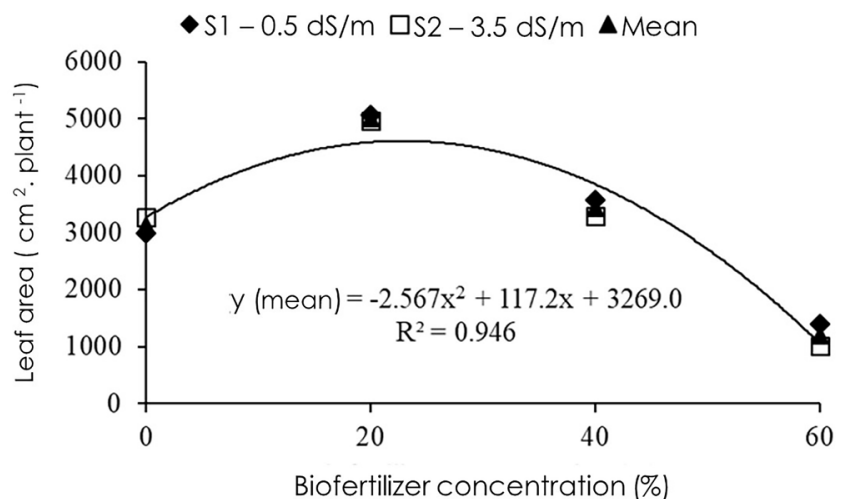

Figure 4. Leaf area of lettuce grown in semi-hydroponics in saline solution and application of biofertilizer via leaf.

leaf area and those presented by these authors can be attributed, in part, to the genetic material used.

A study conducted by Pereira et al. (2010) with bovine biofertilizer produced anaerobically found higher number of leaves under biofertilizer application at concentration of $20 \%$, which is close to the concentration used in the present study that promoted the greatest leaf development.

The use of saline nutrient solution reduced the marketable fresh mass at biofertilizer concentrations of $0 \%$ and $20 \%$ and did not differ at the others (Figure 5). Several authors have shown that the use of saline water either in irrigation (Viana et al., 2001; Oliveira et al., 2011) or in the preparation of the nutrient solution (Dias et al., 2011 ; Santos et al., 2010; Guimarães et al., 2016) causes a significant reduction in lettuce fresh mass production. Also in Figure 5, it can be observed that there was a response to the increase in biofertilizer concentration for both levels of salinity, at which the highest values were obtained at biofertilizer concentrations of 18.80 and $17.01 \%$, with maximum values of 169.24 and $124.53 \mathrm{~g}$ for salinity levels $\mathrm{S} 1$ and $\mathrm{S} 2$, respectively.

$\bullet \mathrm{S} 1-0.5 \mathrm{dS} / \mathrm{m} \quad \square \mathrm{S} 2-3.5 \mathrm{dS} / \mathrm{m}$

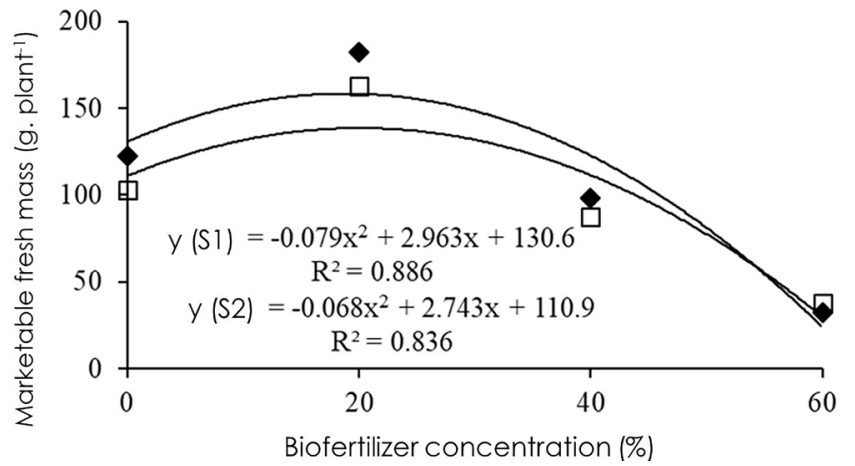

Figure 5. Marketable fresh mass of lettuce grown in semi-hydroponics in saline solution and under foliar application of biofertilizer.

In relation to the total dry mass, as observed for fresh mass, there was also a significant difference between the levels of salinity at biofertilizer concentrations of 0 
and $20 \%$, and salt stress caused reduction of this variable (Figure 6). Regarding the effect of biofertilizer, there was a quadratic response at both levels of salinity, with higher values occurring at the concentrations of $24.46 \%(12.24$ g) and $19.39 \%$ (9.68 g). In a study conducted by Pereira et al. (2010), higher dry mass production was observed in lettuce plants subjected to a concentration of $20 \%$, which is close to the one that promoted the highest value of dry mass in the present study.

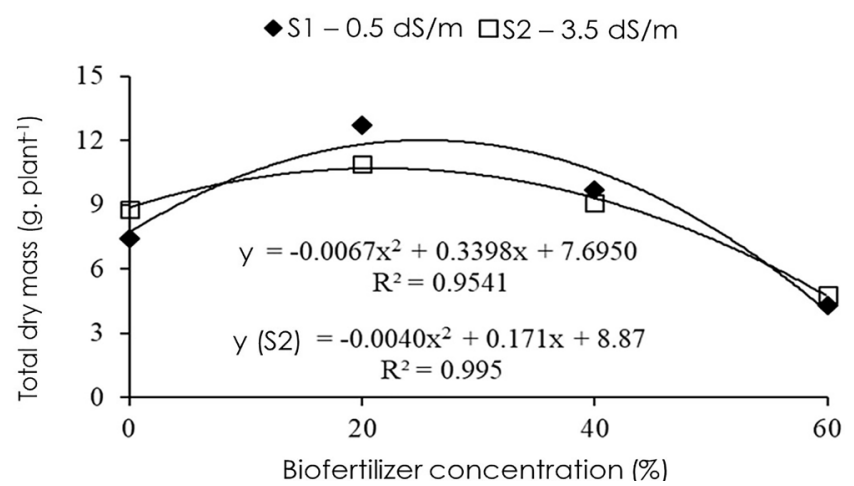

Figure 6. Total dry mass of lettuce grown in semi-hydroponics in saline solution and under foliar application of biofertilizer.

Negative response of lettuce under salt stress in terms of biomass accumulation has been observed by several authors (Oliveira et al., 2011; Dias et al., 2011; Guimarães et al., 2016; Paulus et al., 2012).

The reduction in dry mass accumulation in plants subjected to salt stress is due to excessive accumulation of salts in the substrate solution, which modifies the metabolic activities of cells in the cell elongation process, limiting cell wall elasticity and reducing cell elongation and, as a consequence, plant growth (Taiz et al., 2017).

According to Munns (2005), one of the main effects of salinity on non-salt tolerant crops is the reduction in the photosynthetic rate; this effect occurs mainly due to the excessive accumulation of toxic ions, disorders in mineral nutrition and/or reduction in turgor, which favor the inhibition of leaf expansion, affecting the photosynthetic process and consequently reducing the production of photoassimilates. According to Pereira et al. (2010), the reduction in lettuce dry mass at high concentrations of biofertilizers is due to the nutritional imbalance in the plant, which contributed to a lower growth and consequently a reduced value for this characteristic.

The specific leaf area (SLA) was affected by salinity only at the highest concentration of biofertilizer (60\%), with a reduction of $39.44 \%$. There was no effect of biofertilizer on SLA at the lowest level of salinity, and its average value was $413.2 \mathrm{~cm}^{2} \mathrm{~g}^{-1}$ LDM. On the other hand, plants subjected to salt stress showed quadratic response to biofertilizer, with the highest value $\left(366.27 \mathrm{~cm}^{2} \mathrm{~g}^{-1} \mathrm{LDM}\right)$ occurring at a concentration of $19.66 \%$, and reduction from this concentration, so that the lowest SLA occurred at concentration of $60 \%$ (250.12 $\mathrm{cm}^{2} \mathrm{~g}^{-1}$ LDM) (Figure 7).

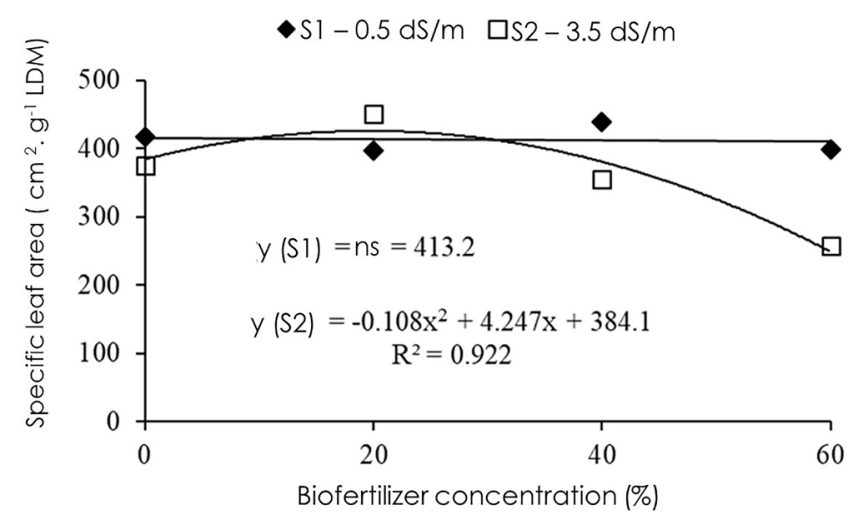

Figure 7. Specific leaf area of lettuce grown in semi-hydroponics in saline solution and under foliar application of biofertilizer.

SLA represents the relationship between leaf blade area and leaf mass and indicates leaf thickness, so that the lower the SLA, the thicker the leaf blade. Thus, plants cultivated in the absence of salt stress did not have leaf thickness affected by the biofertilizer, while under the salt stress condition, the application of biofertilizer at the maximum concentration resulted in thicker and, consequently, more coriaceous leaves. Paulus et al. (2012) verified that the plants subjected to increasing levels of salinity were less tender, exhibiting more coriaceous leaves.

For leaf succulence, plants cultivated without salt stress were superior to plants fertigated with saline nutrient solution in the absence of biofertilizer; however, they were inferior at the biofertilizer concentrations of 40 and $60 \%$ (Figure 8 ).

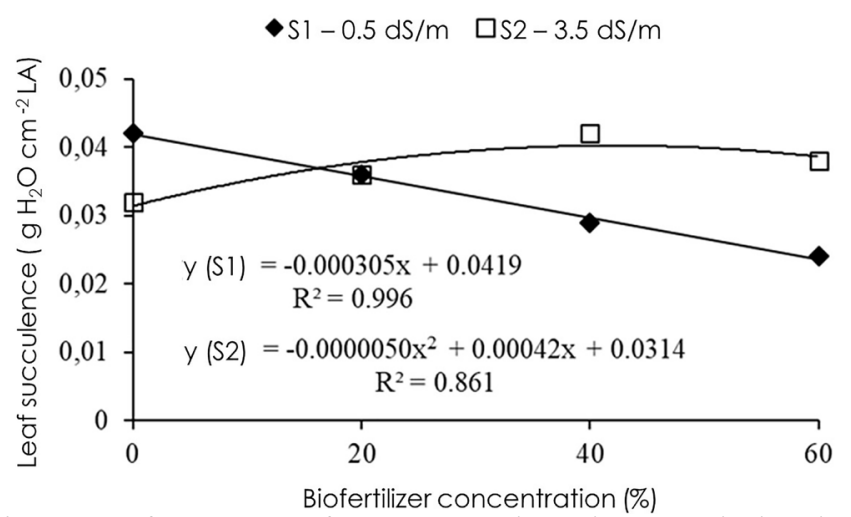

Figure 8. Leaf succulence of lettuce grown in semi-hydroponics in saline solution and under foliar application of biofertilizer.

Regarding the effect of biofertilizer, it can be observed that in the absence of salt stress the increase in the concentrations of this input linearly reduced leaf succulence, from $0.049 \mathrm{~g} \mathrm{H}_{2} \mathrm{O} \mathrm{cm}-2$ to $0.0236 \mathrm{~g} \mathrm{H}_{2} \mathrm{O} \mathrm{cm}{ }^{-2}$ at the concentration of $60 \%$. Plants subjected to salt 
stress showed a quadratic response, with greater leaf succulence occurring at the biofertilizer concentration of $40 \%\left(0.040 \mathrm{~g} \mathrm{H}_{2} \mathrm{O} \mathrm{cm}-2\right)$, with no major variations from this concentration.

In a study conducted with potato, Santos et al. (2009) verified that the use of biofertilizer at concentrations higher than $20 \%$ promoted a decrease in tuber production as the concentration increased. According to these authors, this was possibly due to the increase in nitrogen and water contents in plant tissue above the optimum level for the crop, causing increased electrical conductivity and nutritional imbalance, with a negative impact on potato yield (Santos ef al., 2009). Similarly, Pinheiro \& Barreto (2000) obtained increases in marketable production as a function of sprays with biofertilizer produced with cattle manure at concentration of $20 \%$, both in greenhouses and under open field conditions, with cucumber, eggplant, tomato, lettuce and bell pepper.

\section{Conclusions}

The use of saline water to prepare the nutrient solution reduces fresh mass and dry mass production in lettuce crop.

The biofertilizer can be applied through the leaves at a concentration of up to $20 \%$, promoting greater growth of lettuce plants.

\section{References}

Araújo, S.D.A. 2011. Região Semiárida do Nordeste do Brasil; Questões Ambientais e possibilidades de Uso Sustentável dos Recursos. Revista Científica da FASETE 5: 89-98.

Dias, N.S., Jales, A.G.O., Sousa Neto, O.N., Gonzaga, M.I.S., Queiroz, I.S.R., Porto, M.A.F. 2011 . Uso de rejeito da dessalinização na solução nutritiva da alface, cultivada em fibra de coco. Revista Ceres 58: 632-637.

Ferreira, D.F. 2011 . Sisvar: A computer statistical analysis system. Ciência e Agrotecnologia 35: 1039-1042.

Gomes, J.W.S., Dias, N.S., Oliveira, A.M., Blanco, F.F., Sousa Neto, O.N. 2011. Crescimento e produção de tomate cereja em sistema hidropônico com rejeito de dessalinização. Revista Ciência Agronômica 42: 850-856.

Guimarães, I.P., Oliveira, F.A., Torres, S.B., Pereira, F.E.C.B., França, F.D., Oliveira, M.K.T. 2016. Uso de água residuária da piscicultura no cultivo de alface. Revista Brasileira de Engenharia Agrícola e Ambiental 20: 728-733.

Holanda, J.S., Amorim, J.R.A., Ferreira N.M., Holanda, A.C. 2010. Qualidade da água para irrigação. In: Gheyi, H.R., Dias, N.S., Lacerda, C.F. (eds.) Manejo da salinidade na agricultura: Estudo básico e aplicado. INCTSal, Fortaleza, Brazil. p. 43-61.
Mesquita, F.O., Rodrigues, R.M., Medeiros, R.F., Cavalcante, L.F., Batista, R.O. 2012. Crescimento inicial de Carica papaya sob irrigação com águas salinas em solo com biofertilizante bovino. Semina: Ciências Agrárias 33: $2689-2704$.

Munns, R. 2005. Genes and salt tolerance: Bring them together. New Phytologist 143: 645-663.

Oliveira, F.A., Campos, M.S., Oliveira, F.R.A., Oliveira, M.K.T., Medeiros, J.F., Melo, T.K. 2011. Desenvolvimento e concentração de nitrogênio, fósforo e potássio no tecido foliar da berinjela em função da salinidade. Revista Brasileira de Ciências Agrárias 6: 37-45.

Paulus, D., Dourado Neto, D., Frizzone, J.A., Soares, T.M. 2010. Produção e indicadores fisiológicos de alface sob hidroponia com água salina. Horticultura Brasileira 28: 2935.

Paulus, D., Dourado Neto, D., Paulus, E. 2012. Análise sensorial, teores de nitrato e de nutrientes de alface cultivada em hidroponia sob águas salinas. Horticultura Brasileira 30: 18-25.

Pereira, M.A.B., Silva, J.C., Mata, J.F., Silva, J.C., Freitas, G.A., Santos, L.B., Nascimento, I.R. 2010. Uso de biofertilizante foliar em adubação de cobertura da alface cv. Verônica. Pesquisa Aplicada \& Agrotecnologia 3: 129-134.

Pinheiro, S., Barreto, S.B. 2000. Mb-4: agricultura sustentável, trofobiose e biofertilizantes. MIBASA, Alagoas, Brazil. 273 p.

Santos Júnior, J.A., Gheyi, H.R., Dias, N.S., Guedes Filho, D.H. 2015. Crescimento do girassol em sistema semihidropônico sob estresse salino e densidades de plantio. Revista Brasileira de Agricultura Irrigada 20: 233-247.

Santos, J.F., Sousa, M.R., Santos, M.C.C.A. 2009. Resposta da batata-doce (Ipomoea batatas) à adubação orgânica. Tecnologia \& Ciência Agropecuária 3: 13-16.

Santos, R.S.S., Dias, N.S., Duarte, S.N., Lima, C.J.G.S. 2012. Uso de águas salobras na produção de rúcula cultivada em substrato de fibra de coco. Revista Caatinga 25: 113118.

Santos, R.S.S., Dias, N.S., Sousa Neto, O.N., Gurgel, M.T. 2010. Uso do rejeito da dessalinização de água salobra no cultivo da alface (Lactuca sativa L.) em sistema hidropônico. Ciência e Agrotecnologia 34: 983-989.

Silva, E.F.F., Campeche, L.F.S.M., Duarte, S.N., Folegatti, M.V. 2005. Evapotranspiração, coeficiente de cultivo e de salinidade para o pimentão cultivado em estufa. Magistra 17: 58-63.

Silva, F.L.B., Lacerda, C.F., Neves, A.L.R., Sousa, G.G., Sousa, C.H.C., Ferreira, F.J. 2013. Irrigação com águas salinas e uso de biofertilizante bovino nas trocas gasosas e produtividade de feijão-de-corda. Irriga 18: 304-317.

Silva, F.L.B., Lacerda, C.F., Sousa, G.G., Neves, A.L.R., Silva, G.L., Sousa, C.H.C. 201 1. Interação entre salinidade e biofertilizante bovino na cultura do feijão-de-corda. 
Revista Brasileira de Engenharia Agrícola e Ambiental 15: 383-389.

Soares, T.M., Duarte, S.N., Silva, E.F.F., Jorge, C.A. 2010. Combinação de águas doce e salobra para a produção de alface hidropônica. Revista Brasileira de Engenharia Agrícola e Ambiental 14: 705-714.

Soares, T.M., Silva, E.F.F., Duarte, S.N., Melo R.F., Jorge, C.A., Bonfim, E.M. 2007. Produção de alface utilizando águas salobras em sistema hidropônico. Irriga 12: 235-248.

Sousa, G.G., Marinho, A.B., Albuquerque, A.H.P., Viana, T.V.A., Azevedo, B.M. 2012. Crescimento inicial do milho sob diferentes concentrações de biofertilizante bovino irrigado com águas salinas. Ciência Agronômica 43: $237-$ 245.

Souza, M.S., Alves, S.S.V., Dombroski, J.L.D., Freitas, J.D.B., Aroucha, E.M.M. 2012. Comparação de métodos de mensuração de área foliar para a cultura da melancia. Pesquisa Agropecuária Tropical 42: 241-245.

Taiz, L., Zeiger, E., Moller, I.M., Murphy, A. 2017. Fisiologia e desenvolvimento Vegetal. Artmed, Porto Alegre, Brazil. $858 \mathrm{p}$.

Viana, S.B.A., Rodrigues, L.N., Fernandes, P.D., Gheyi, H.R. 2001. Produção de alface em condições de salinidade a partir de mudas produzidas com e sem estresse salino. Revista Brasileira de Engenharia Agrícola e Ambiental 5: 60-66.

Conflict of Interest Statement: The authors declare that the research was conducted in the absence of any commercial or financial relationships that could be construed as a potential conflict of interest.

All the contents of this journal, except where otherwise noted, is licensed under a Creative Commons Attribution License attribuition-type BY. 